\title{
Den

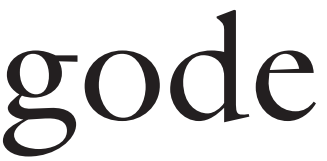 \\ samaritaner og den gode flygtning \\ - forestillinger om køn i humanitær diskurs og praksis
}

\section{Af Simon Turner}

I bumanitar diskurs må en flygtning vare et uskyldigt og hjalpelost offer for at kunne retfardiggøre hjalpeindsatsen. Sådanne forestillinger er sterkt kønnede og kommer til udtryk $i$ daglige praksisser i flygtningelejre. Men bvad gor man, nà flygtningene ikke vil opfore sig som ofre?

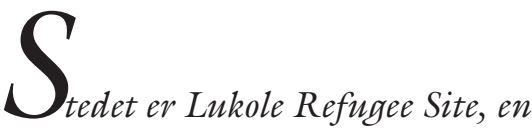

lejr $i$ det nordvestlige Tanzania med omtrent et hundrede tusinde flygtninge fra Burundi. Jeg sidder $i$ UNHCR's bygning sammen med en tanzaniansk 'field assistant' fra UNHCR, representanter fra OXFAM og Tanzaniansk Røde Kors og omtrent type flygtningerepresentanter. De sidstnavnte er ledere for de enkelte 'landsbyer' i lejren. Samtlige tilstedeverende ledere er mond - overraskende mange er unge, helt ned til tyvearsalderen. Representanterne fra NGOerne er mandlige og kvindelige tanzanianere og UNHCRs reprasentant er en ung kvinde. ${ }^{1}$ Hun taler venligt til lederne $i$ det lokale sprog kibangaza, som forstås på begge sider af gronsen. Stemningen bliver dog trykket og hendes attitude mere paternalistisk, da hun krover lister over kandidater til nogle komitéer, der skal nedsattes i hver enkelt landsby. Mendene kigger ned og skraber $i$ det sandede gulv med fodderne. Nogle mumler noget uforståeligt og andre kommer med doirlige undskyldninger. Hun skruer bissen på: De havde aftalt, 
at hver landsby skulle lave en komité med tre kvinder og tre mand $i$ hver. Hvor bliver listerne af? Efter en reprimande, beder bun dem om at oppe sig og gore noget ved sagen inden neste mode om fjorten dage. Hun går videre til neste punkt på dagsordenen: problemer med flygtninge, der ikke bygger lokummer efter de udstukne retningslinjer.

Ovenstående oplevelse fra mit feltarbejde i 1997-1998 sætter en del på spil om køn og magt i flygtningesituationer, der illustrerer forholdet mellem flygtningene og de organisationer, der er sat til at 'hjælpe' og administrere dem. Det stiller spørgsmål ved indgroede forestillinger om flygtninge som passive ofre; og bagved organisationernes ønsker om kvindelig deltagelse ligger der også indgroede forestillinger om krig, køn og flugt. I denne artikel vil jeg undersøge, hvorledes nødhjælpsorganisationers hjælpearbejde indlejres i forestillinger om krigens ofre og bødler, og hvorledes disse forestillinger er kønnede. Jeg vil vise, hvorledes kvinder i disse forestillinger inkarnerer den xgte flygtning - det uskyldige offer for andres handlinger - mens især unge mænd anses som en trussel mod de apolitiske og humanitære mål i nødhjælpsarbejdet. Jeg vil undersøge dels, hvordan disse forestillinger kommer til udtryk i humanitær diskurs og dels, hvordan dette udspiller sig i daglig praksis - som i tilfældet ovenfor.

\section{KRIGENS OFRE}

Det hævdes ofte, at størstedelen af verdens flygtninge er kvinder. Selvom det statistisk er blevet tilbagevist flere gange, ${ }^{2}$ bliver denne populære forestilling ved med at leve videre $\mathrm{i}$ diverse populære fremstillinger $\mathrm{i}$ nødhjælpsbranchen. Ofte sættes kvinder og børn i samme kategori i disse erklæringer, som når UNHCR på sin hjemmeside erklærer:

"Among the people hit hardest by the violence and uncertainty of displacement are girls, elderly widows, single mothers - women. As a rule of thumb, some 75 per cent of these destitute displaced people are women and their dependent children. (UNHCR Fundraising: The General Programmes UNHCR's Core Activities": http://www.unhor.ch/fdrs/gpapp, 4).

I et UNHCR dokument om organisationens politik på kvindeområdet udtrykkes det, at et mål er at anerkende at 'refugee women represent, either as single women or with their dependents, approximately 80 per cent of UNHCR's target population...' (Executive Committee of The High Commissioner's Programme). Ved at sætte kvinder i samme bås som børn er man med til at fratage dem enhver form for kontrol over eget liv - for slet ikke at tale om politisk subjektivitet. De reduceres til hjælpeløse ofre for omstændighederne uden at være i stand til at tage vare på deres eget liv.

Feministiske forskere har forsøgt at mane denne myte $\mathrm{i}$ jorden ved at vise, hvorledes kvinder faktisk udviser initiativ og styrke i flygtningesituationer. Ofte klarer kvinder sig faktisk bedre end mænd i de nye omgivelser (Daley 1991; Hyndman 2000; Indra 1999; Moser and Clark 2001). Men forestillingen om kvinden som det uskyldige offer lever videre. Ann Varley har ved grundige gennemgange af statistisk materiale fundet, at lignende lemfældig brug af tal gør sig gældende i andre fremstillinger af kvinder $\mathrm{i}$ den tredje verden (Varley 1995; Varley 1996). Baggrunden for denne form for overdrivelse er, ifølge Varley, at man ser kvinder fra den tredje verden som enten ofre eller heltinder og bruger tallene til at forstærke dette billede. I ovenstående UNHCR citat stilles følelsesladede udtryk som 'destitute' side om side med nøgtern tal (75\%). Således bruges tallet til at validere forestillingen om kvinder som ofre. Jo flere der er, desto større synes elendigheden at være. Det er ikke, fordi UNHCR på nogen måde forsøger at nedgøre eller undertrykke kvinder, når 


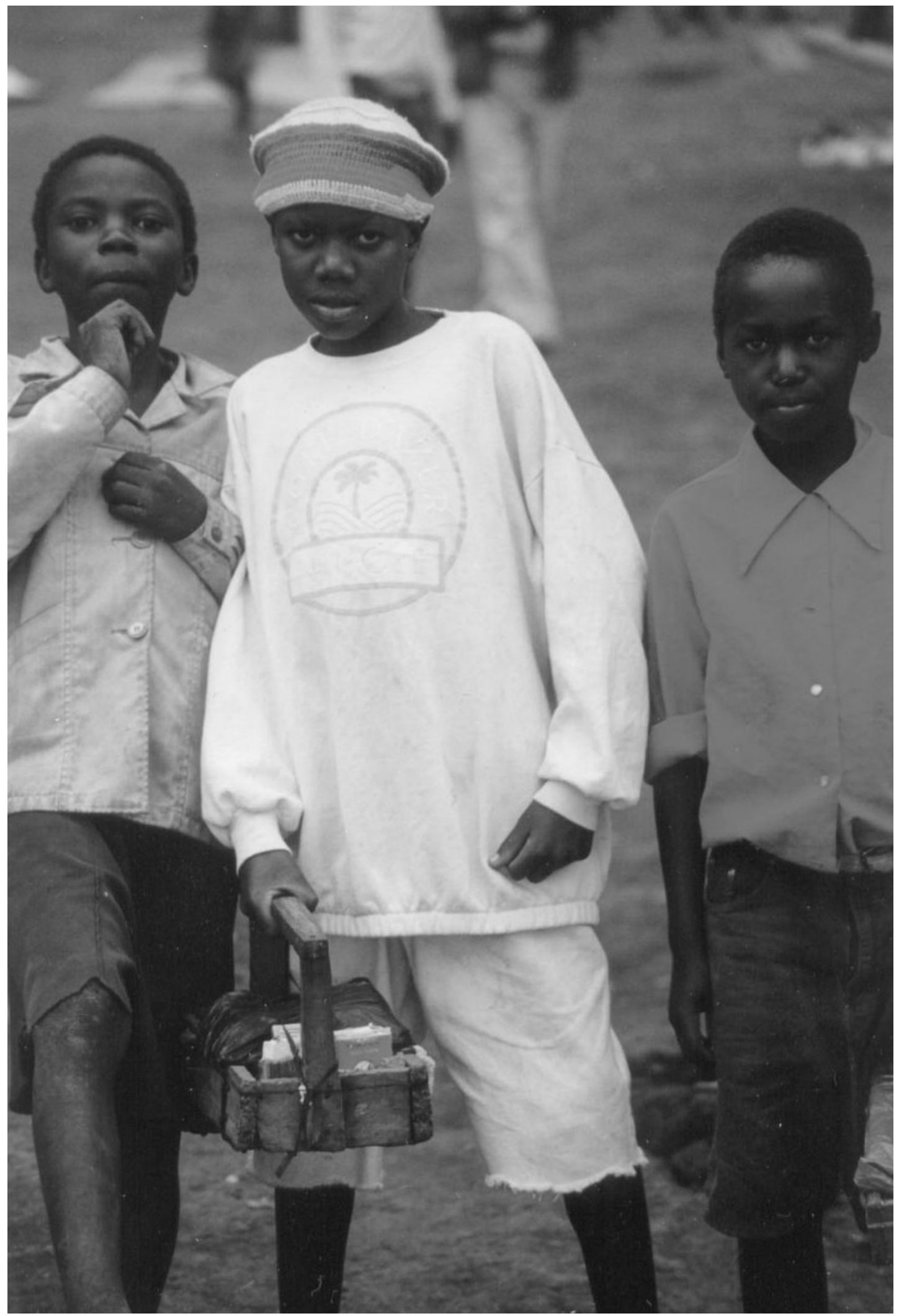


kvinder sættes i samme kategori som børn. Tværtimod appellerer ovenstående citat til at støtte kvinder i nød ved at appellere til vores medmenneskelige medfølelse. Det er også et forsøg på at vise, at flygtninge virkelig er ofre og derved uden skyld i den situation, de er havnet i. Og hvem kan bekræfte det billede bedre end kvinder og børn? Derved er der skabt en cirkelslutning, der bygger på den præmis, at læseren også automatisk antager, at kvinder og børn er 'xgte ofre' - ligesom når antallet af dræbte kvinder og børn altid nævnes i reportager fra krigshandlinger. Man spiller med andre ord på gængse forestillinger om krigens ofre og krigens skurke. Kvinder kan man - ligesom børn - have medlidenhed med og hjælpe, hvilket retfærdiggør nødhjælpsorganisationernes humanitære indsats. Hvor Varley argumenterer, at kvinder fremstilles som uskyldige ofre gennem overdrevet statistik, har disse fremstillinger den dobbelte rolle også at fremstille flygtninge som hjælpeløse ofre. Billedet af den uskyldige flygtning og - den barnagtige kvinde bekræfter hinanden. Ved en gennemgang af UNHCR kalendere finder Liisa Malkki, at så godt som alle billeder forestiller kvinder eller børn:

"Perhaps it is that women and children embody a special kind of powerlessness; perhaps they do not tend to look as if they could be "dangerous aliens"; perhaps their images are more effective in fund-raising efforts than those of men". (Malkki 1995, 11).

Disse billeder af kvinder og børn repræsenterer ren menneskelighed (humanity) uden historie eller politiske overbevisninger. Mænd på den anden side repræsenterer bagsiden af gængse forestillinger om flygtninge, siger hun. De repræsenterer truslen, der bringer fremmede kulturer og farlige, politiske holdninger med sig. For mens flygtningen i den dominante vestlige diskurs på mange måder konstrueres som en, der har mistet alt (Soguk 1999), så er det også en ambivalent konstruktion, der tillige bygger på forestillinger om truslen mod kulturel og politisk stabilitet. Ravinder Kaur argumenterer på lignende vis, at selve det at flygte anses som en emaskulerende handling:

“Any possibility of heroism $[\ldots]$ is lost or at least minimised with the act of fleeing that is associated with the feminine goal of preservation of life". (Kahr 2003, 11).

Det at redde liv og tage flugten frem for kampen er altså en kvindelig strategi set ud fra essentialistiske holdninger til kønnet. Kaur nævner dog, at vi her må skelne mellem de 'almindelige mennesker', der undslipper krig og de politisk aktive individer, der bruger eksilet som en strategisk tilbagetrækning i kampen. Sidstnævnte er tydeligvis både heroisk og maskulint, set fra et politisk-ideologisk synspunkt. Set fra et humanitært synspunkt er det dog en problematisk kategori, da den bryder med det stereotype billede af det hjælpeløse offer for ydre omstændigheder. Det vil sige, at forestillingen om flygtninge igen er ambivalent i de dominante diskurser. I det følgende ser vi, hvorledes nødhjælpsdiskursen forsøger at håndtere og eliminere denne ambivalens igennem administrative praksisser i lejren for på den måde at bibeholde det rene billede af flygtningen som offer, der fortjener empati og hjælp. Dette opnås blandt andet ved at skelne mellem mandlige og kvindelige flygtninge. I en fascinerende antologi om køn og krig påpeger Moser og Clark, at der er en generel tendens til at essentialisere køn i konfliktsituationer. De tilføjer, at denne tendens gør både mænd og kvinder til objekter, hvilket fratager dem deres subjektivitet og deres plads som handlende aktører (Moser and Clark 2001).

I sin grundige historiske analyse af UNHCR viser Nevzat Soguk, at flygtningefiguren er en figur, der har mistet alt: hjem, nation og borgerskabsrettigheder. Han argumenterer for, at flygtningen derved kon- 
strueres som den 'nødvendige anden', der er med til at forstærke forestillingen om den naturgivne sammenhæng mellem nation, stat og borger. Alt hvad hun mangler, antages 'vi' at have, hvilket er med til at stabilisere en ellers prekær national orden. Men ikke nok med, at flygtninge fremstilles som den, der mangler nation og stat; flygtningen mangler derved også 'proper agency, proper voice, proper face' (Soguk 1999, 243). Kun da, når flygtningen fremstilles som uden 'agency', kan vi håndtere flygtningen og hjælpe. Kun hvis flygtningen fremstår som en, der mangler alt det, vi har, kan vi hjælpe hende og give hende det, hun mangler. Desuden muliggør denne produktion af flygtninge som hjælpeløse ofre i humanitær diskurs vestlige eksperters vidensproduktion. Denne viden er de humanitxre organisationers raison d'être (Rajaram 2002). Men ikke alle flygtninge opfører sig som uskyldige ofre. Ikke alle flygtninge er entydigt ofre for krigens vold. Dette giver kurrer på tråden og kræver, at nødhjælpsorganisationer iværksætter ganske bestemte praksisser for at opretholde idéen om offeret; praksisser som 'kønner' flygtningene.

I det følgende ser vi, hvorledes disse meget overordnede diskurser sætter sig igennem i praksis i lejren. Det skal kort bemærkes, at UNHCR selvfølgelig ikke er en monolitisk aktør med én vilje. Der er mange spændinger mellem forskellige faggrupper, ligesom der er spændinger mellem folk i felten og på hovedkontoret i Geneve. Ligeledes er der også stor forskel på den måde, forskellige NGOer opererer på. En analyse af disse forhold ligger uden for rammerne af denne artikel, hvor fokus holdes på nogle generelle tendenser. ${ }^{3}$

\section{AT HJÆLPE OFFERET}

I Lukole-lejren har FN og en række NGOer fra Vesten formået at etablere en velsmurt 'operation', der sørger for at levere mad, vand, medicin og andre basale fornødenheder til 100.000 mennesker $i$ en af
Tanzanias fjernest liggende og mest underudviklede distrikter. De enorme mængder nødhjælp fragtes tværs over landet ad veje, der får Camel Trophy til at ligne autobahnkørsel. Alt er nøje planlagt og udregnet. UNHCR, der står for koordineringen, har en 'Site Planner', der beregner den ideelle placering af lejren og tegner et net af snorlige hoved- og biveje, der optimerer adgangen til lejren. En 'Water and Sanitation Officer' sørger for, at vandhanerne står med regelmæssige mellemrum, så ingen flygtning behøver at gå mere end 150 meter efter vand. Der beregnes 11 liter vand per person per dag. Hun sørger også for, at flygtninge graver lokummer af en vis dybde og bredde med en vis afstand fra deres stråhytter. Således sørger eksperter for den optimale og mest effektive løsning på forskellige behov. Dødeligheden i lejren er da også lavere end i de omkringliggende tanzanianske landsbyer.

I den mere 'bløde' ende sørger UNHCRs 'Community Service Officer' for at hjælpe diverse 'sårbare grupper' og for flygtningenes velvære på det mere sociale plan. Tidligere hed det 'Social Services', men skiftede i midten af halvfemserne navn til 'Community Services', og siden år 2000 har UNHCR søgt at omskabe det til 'Community Development'. UNHCRs community services officer forklarede mig, at navneskiftet afspejlede et forsøg på at gå fra at servicere den enkelte til at støtte 'the community' i at hjælpe sig selv. Man skulle så at sige 'løfte' flygtningesamfundet som helhed, så 'the community' kunne lære at tage vare på sig selv. Således gik de flygtninge, der tidligere havde været ansat som 'social workers' over til at være 'community mobilisers'. Der findes ikke noget dansk ord for begrebet community, der har en lang række konnotationer, der omfatter meget mere end lokalsamfund. Det er netop alle disse udefinerbare konnotationer, der giver begrebet dets sublime evner. Som Elizabeth Frazer siger, transcenderer 'community' summen af sociale relationer (Fraz- 
er 1999, 85). Der ligger en romantisk søgen efter Gemeinschaft, hvor individer har fælles interesser og mål, og hvor de finder deres sande interesser, upåvirket af magt og politik (Taylor 1994, 28-29). Det er endvidere en grundlæggende antagelse i participationsstrategien, at 'the community' er en enhed, der eksisterer (og ikke en kontekstafhængig konstruktion); den skal blot findes frem og have lov til at blive hørt (Cruikshank 1999).

Op gennem halvfemserne var man i nødhjælpskredse blevet mere og mere bange for, at det fantastisk effektive, bureaukratiske apparat, man havde fået etableret, og som kunne redde millioner af menneskeliv, måske havde en bagside. Debatten om det, der blev kaldt afhængighedssyndromet, rasede i akademiske kredse (Hall-Matthews 1996; Harrell-Bond 1986; Kibreab 1993). Man mente, at den hjælp, som man gav til flygtninge, skabte en 'nødhjælpsmentalitet' og at flygtninge blev apatiske og ude af stand til at tage hånd om egne problemer, fordi de blev opvartet af donorer. Løsningen var selvfølgelig ikke at tage rationerne fra dem, hvilket ville medføre en humanitær katastrofe. Derimod syntes løsningen at ligge $i$ at give flygtningene større medbestemmelse; hvis de fik større indflydelse på eget liv, ville de ikke forfalde til apati og afhængighed, lød argumentet. Dette var selvfølgelig stærkt inspireret af lignende debatter om 'folkelig deltagelse' (participation), som havde kørt i udviklingsteorier siden 1980-erne. ${ }^{4}$ En af de mere 'progressive' NGOere i lejren, britiske Christian Outreach, var langt fremme med disse tanker og talte også direkte om udvikling frem for nødhjælp i lejren. Som Richard Reynolds, organisationens leder i Lukole, udtrykker det:

"A development philosophy, as opposed to relief mentality, can ensure that the communities within the camp population can develop themselves and their capacities...”

(Reynolds 1996).
Målet er altså at fjerne nødhjælpsmentaliteten og skabe en værdig og stærk 'community'. Men ifølge Reynolds skyldes flygtningenes manglende selvværd og deres behov for 'community development' ikke kun den pacificerende og topstyrede nødhjælp. Det er også et resultat af selve flugten:

"In a refugee situation people, often over night, lose their country, home and livelihood, and are told or ordered where to live, what to eat and what they can do. Refugees suddenly become disempowered and dependent on others" " (Reynolds 1995).

Flugten bliver her fremstillet som en paniksituation, hvor man ikke har noget valg og ikke har kontrol over eget liv. Han antager, at det samfund, der eksisterede før krigen, splintres, og folk kommer til lejren som løsrevne atomer uden magt eller værdighed. Senere i samme artikel siger han, at man med udviklingsprogrammer kan involvere dem i beslutningsprocesser og derved give dem deres værdighed tilbage. Mine livshistorieinterviews med flygtninge viste, at deres beslutning om at flygte har været en meget mere kompleks proces. Ofte er det foregået over flere tempi og har indbefattet en række strategiske valg. De har med andre ord handlet som strategiske individer gennem hele processen og har ikke mistet deres evne til at tage beslutninger; blot har betingelserne omkring deres beslutninger været meget barske.

Tanken om, at flygtninge skulle udgøre samfund, der er gået i opløsning, går igen i megen nødhjælpstankegang. I en FN-håndbog om beskyttelse af flygtningekvinder anbefaler man, at kvinder inddrages $\mathrm{i}$ de beslutningsprocesser, der vedrører dem (UNHCR 1991, 10). Samme dokument siger videre, at nødhjælpsarbejdere måske vil indvende, at sådanne forsøg på at inddrage kvinder $\mathrm{i}$ beslutnings-processen går imod den lokale kultur. Til dette siger forfatterne, at kvinder rigtignok ofte har haft mulighed for at udtrykke sig i deres 
oprindelige kultur. Det er bemærkelsesværdigt, at dokumentet på bedste kulturrelativistisk vis nævner, at kvinder traditionelt kunne udtrykke deres problemer og behov gennem deres mænd. I flygtningesituationen er sådanne traditionelle mekanismer imidlertid brudt sammen og nye, alternative strukturer må sættes i stedet, hedder det i dokumentet. Vi kan med andre ord se, at diskursen om at inddrage flygtninge udspringer dels af en antagelse om, at nødhjælp skaber et afhængighedssyndrom og dels af en antagelse om, at en harmonisk normaltilstand, hvor alle kom til orde, er brudt sammen med krig og flugt. I en stærkt kritisk artikel argumenterer Mark Duffield ligeledes for, at nødhjælpsorganisationer har et funktionalistisk og kulturalistisk syn på konflikt, hvor normaltilstanden antages som værende $\mathrm{i}$ en ligevægtstilstand uden konflikt og spænding (Duffield 1996). Duffield påpeger (i lighed med Marxismen og post-strukturalismen), at alle samfund er bygget op omkring grundlæggende antagonismer, som ikke blot er uløselige men også historiens drivkraft. Når nødhjælpsorganisationer ikke indser, at konflikt er normaltilstanden, bliver de ude af stand til at analysere magt og politiske processer. Derved kan deres såkaldt apolitiske indgreb have uheldige utilsigtede konsekvenser. Det er denne kulturalisme og funktionalisme og denne institutionelle blindhed for magt og interesser, der ligger bag de humanitære organisationers forsøg på at fremelske et harmonisk, konfliktfrit 'community', hvor flygtningesamfundet kan udtrykke dets ønsker og behov uden politiske egeninteresser.

\section{NÅR OFFERET IKKE OPFØRER SIG SOM OFFER}

I Lukole flygtningelejr søgte man at inddrage flygtningene ved for eksempel at kræve, at flygtningene udpegede ledere blandt sig. Det var disse ledere, vi så i introduktionen. De skulle være bindeleddet

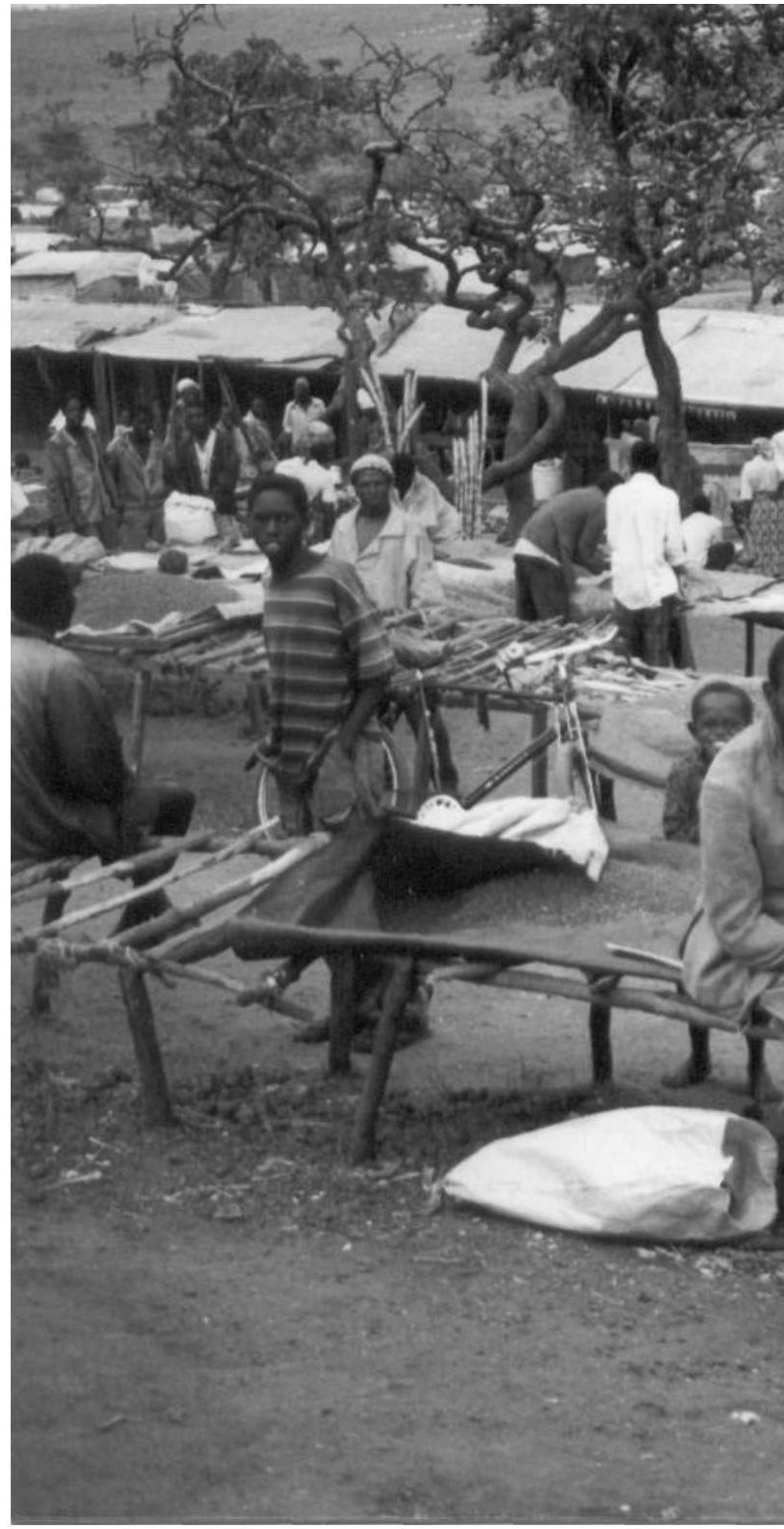

mellem befolkningen og organisationerne og varetage og udtrykke 'the community's' interesser. Så skulle man da tro, at alt var i den skønneste orden. Men det var det ikke. FN og NGOerne var ikke tilfredse med lederne. Det var derfor, den unge kvinde fra 


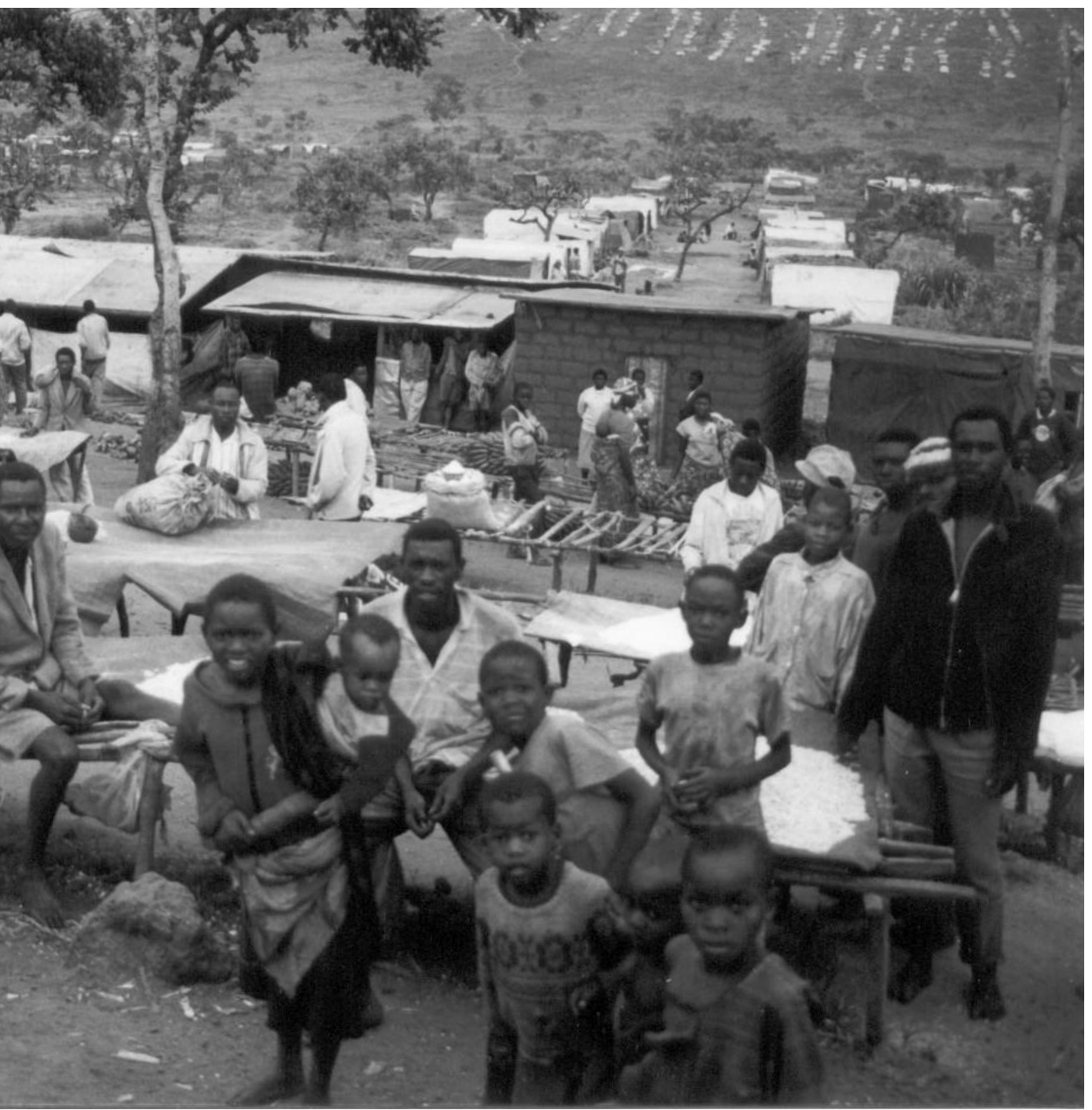

Foto: Simon Turner

FN pressede lederne til at lave disse komitéer med tre mænd og tre kvinder. Man forsøgte sig også med kvindekomitéer. Hvorfor var det, de var utilfredse med lederne? Svaret ligger i de opfattelser, organisationerne havde af, hvad 'rigtig' folkelig deltagelse er. Det er nemlig ikke ligegyldigt, hvordan man deltager eller hvem der deltager.

I sommeren 1997 havde der været uroligheder i lejren. Folk blev slået ihjel, og mange flygtede fra den ene del af lejren til 
den anden. Det er svært at afgøre præcist, hvad kampene drejede sig om, men der er ingen tvivl om, at de havde politiske overtoner, hvor de to dominerende partier i lejren, Palipehutu (Parti pour la Libération du Peuple Hutu) og CNDD (Conseil National pour la Défence de la Démocratie), kæmpede om magten. Situationen tilspidsedes, da chefen for sikkerhedsvagterne, ansat af UNHCR til at holde ro og orden i lejren, anklagede chefen for alle flygtningelederne for at være involveret i politik og for kun at hjælpe sine partifæller. Omvendt fik UNHCR et brev fra flygtningelederne, hvori de bad om, at chefen for sikkerhedvagterne blev fyret på grund af magtmisbrug. UNHCR reagerede ved at fyre samtlige sikkerhedsvagter og ansætte nye efter at have screenet dem for politisk aktivitet. Sideløbende arrangerede man nye valg af ledere. Til et folkemøde i lejren i forbindelse med ovenstående konflikt mellem sikkerhedsvagterne og lederne, opfordrede UNHCRs 'field officer' (en etiopisk kvinde) flygtningene til at afholde sig fra aktiviteter, der ville ødelægge sikkerheden og ødelægge 'det harmoniske sociale liv for det store flertal af flygtningene, der flygtede fra deres land for at søge fred og sikkerhed'. I forbindelse med de forestående valg af nye ledere rådede hun flygtningene til at vurdere kandidaternes politiske engagement og undgå at vælge individer, der blot ville bruge det til at pleje deres egne politiske interesser på 'uskyldige menneskers bekostning' (feltnoter, maj 1997). Til lederne sagde hun, at de skulle være i stand til at tilsidesætte egne individuelle interesser til fordel for at tjene det folk, der havde valgt dem.

Hvad de ovenstående eksempler fra lejren viser, er, at xgte folkelig deltagelse i UNHCRs øjne er apolitisk. De ser stillingerne som leder og sikkerhedsvagt som rent administrative poster, hvor man leverer service til 'flygtningesamfundet'. Magt indgår slet ikke $\mathrm{i}$ dette regnestykke, ligesom konflikt heller ikke gør. Man havde simpelthen ikke forestillet sig, at der ville være så meget magt forbundet med stillingen som henholdsvis sikkerhedsvagt og leder; og når der er magt forbundet, vil der altid være magtkampe om at bestride posterne, hvilket gør dem politiske. Imidlertid brød dette idealbillede sammen i Lukole, da de, der skulle representere 'the community', begyndte at kæmpe om magten. Godt nok udviser de initiativ og kan ikke anklages for at lide af afhængighedssyndromet. Men de udviser den forkerte slags initiativ ifølge nødhjælpsorganisationernes intentioner. De er strategiske og udnytter situationen til egen fordel, hvilket strider mod forestillingen om flygtningelederen som et neutralt talerør for 'folket' som helhed. FN forestiller sig, at det er 'the community' som helhed, der skal opløftes og styrkes. Richard Reynolds advarer mod at skære ned i støtten til 'community groups', da dette vil efterlade flygtningene uden alternativer og gøre dem 'afhængige af de politiske grupperinger' (Reynolds 1996). Han stiller med andre ord 'community groups' op som en direkte modstilling til politiske ledere. Dette hænger også sammen med hele idéen om xgte flygtninge som uskyldige ofre, som vi så i første afsnit. Da det sagesløse offer i sagens natur ikke har haft indflydelse på sin egen skæbne og er offer for ydre omstændigheder, kan det ikke være involveret i politik. Hvis man begynder at hævde sig politisk, kan der drages tvivl om ens sagesløshed og derved ens uskyld. I en Burundisk kontekst er dette spørgsmål om skyld meget presserende, da mange af disse Hutu flygtninge potentielt har været med til at massakrere deres Tutsi naboer i 199394. Og i Burundi's falske tvilling, Rwanda, stod Hutu-ekstremister bag et af verdens største folkemord i 1994, hvilket har en vis afsmittende effekt på Hutuerne fra Burundi i den internationale opinion. Når flygtningene så aktivt deltager i partipolitik bliver det svært for nødhjælpsorganisationerne at bevare billedet af sagesløse bønder, der flygtede fra volden.

Alligevel formåede nødhjælpsorganisatio- 
nerne at bevare forestillingen om folkelig deltagelse og 'the community'. Som vi kan se i citatet fra folkemødet, skelnede UNHCRs representant skarpt mellem 'det store flertal af uskyldige flygtninge' og så de selviske, magtsyge politikere. På den måde oprettes en dikotomi mellem frllesskabet af ofre på den ene side og nogle få individer, der forhindrer fællesskabet $i$ at realisere sig selv på den anden. Man er i stand til at bevare illusionen om the community's sublime evner ved at projicere dets fallit på disse individer. Samtidig retfærdiggør denne adskillelse mellem det store flertal af ofre og nogle fă individer, der spolerer fællesskabet, at nødhjælpsorganisationerne styrer processen med hård hånd. Man er ikke imod demokrati, men føler sig nødsaget til at kontrollere det, for at det bliver den 'rigtige slags' demokrati.

Disse individer, der udnytter systemet til egen fordel, er sædvanligvis mænd (over 95\% af lederne og sikkerhedsvagterne er mænd), og en del af løsningen for UNHCR synes at være at rekruttere kvinder i disse nøgleposter i lejren. Således bestræbte man sig, i forbindelse med omstruktureringen, på at få ansat kvinder i stillingerne som sikkerhedsvagter, da man antog, at kvinder ville være mindre politisk aktive og bedre mæglere. Dette lykkedes dog kun i meget ringe grad, da meget få kvinder søgte stillingerne. I forbindelse med valg af nye ledere appellerede UNHCR også til, at man stemte på kvindelige kandidater. Jeg overværede valghandlingerne $i$ en af sektionerne i lejren; selvom den eneste kvindelige kandidat kun fik seks stemmer, foreslog UNHCRs repræsentant (en Nigeriansk kvinde, som flygtningene troede var amerikaner på grund af hendes accent og påklædning) efterfølgende, at den valgte leder - en mand på 21 år - samarbejdede tæt med hende.

Disse forsøg på at få kvinder ind på posterne som ledere og sikkerhedsvagter skyldes til dels et eksplicit ønske om at styrke ligestilling i lejren. Men der ligger også stærke kønnede forestillinger bag dette ønske. Der ligger en forestilling om, at kvinder vil være mindre interesserede $\mathrm{i}$ politik, at de vil være mindre voldelige og at de vil varetage fællesskabets interesser bedst muligt. I lejren var der en række aktiviteter målrettet mod kvinder, børn, forældreløse, handicappede, ældre osv. Unge mænd beskxftigede organisationerne sig kun med, når de lavede uro. Således blev de indkaldt til møder, når der havde været politiske kampe eller andre former for vold. De bliver også nævnt i forbindelse med diverse rapporter om militær træning eller seksuelle overgreb i lejrene lejrene (Human Rights Watch 2000; International Crisis Group 1999). Selvom politisk aktivitet blev set som resultatet af en lille minoritets manipulering af det store flertal, var der et behov for at identificere denne lille gruppe. Og selvom man ikke mente, at alle unge mænd var involveret i politik, var alle unge mænd potentielt involverede; således blev unge mænd som kategori mistænkeliggjort. Hvad vi ser af ovenstående er, at lejradministrationen (UNHCR og diverse NGOer) forsøger at opretholde ideen om flygtningen som det rene, uskyldige og hjælpeløse offer ved at skelne mellem det store flertal af sagesløse flygtninge og en lille gruppe, der saboterer processen. Denne opdeling er tendentielt kønnet, idet kvinder antages at inkarnere offeret, mens (især unge) mænd potentielt er sabotører, der underminerer diverse tiltag til at 'empower' flygtningene gennem deres deltagelse i voldelig politik.

\section{KONKLUSION}

Nødhjælpsorganisationer har en stor og oprigtig trang til at hjælpe folk i nød. Næsten alle de nødhjælpsarbejdere, som jeg mødte i Tanzania, ønskede at hjælpe flygtninge. Det viste sig dog svært at udføre denne hjælp i praksis, når flygtningene ikke opførte sig som taknemmelige, hjælpeløse ofre. Det var et problem, når flygtningene var apatiske og ikke tog vare på sig selv eller hinanden. Dette var dog et problem, som 
kunne afhjælpes, idet det ansås som et resultat dels af den topstyrede nødhjælp og dels af flugten fra hjemlandet, der havde ødelagt deres kultur og selvværd. Dette søgte man at rette op på ved at inddrage 'the community'. Der opstod imidlertid andre problemer for disse gode samaritanere, bl.a. at almindelige Hutuer havde slået op mod 30.000 Tutsier ihjel i 1993; hvilket forplumrede billedet af offeret. Idéen om at det var almindelige mennesker, der flygtede fra krydsilden mellem (Hutu) oprørsstyrker og (Tutsi) hæren, fastholder billedet af sagesløse ofre. På den måde undgår man den ubehagelige kendsgerning, at grænsen mellem guerillasoldat og civilbefolkning er flydende - nærmest fiktiv. Det var også et problem, når politisk rivaliseren endte i voldelige episoder i lejren. Hvordan kunne nødhjælpsarbejderen forsone disse hændelser med deres ønske om at styrke fællesskabet?

I denne artikel har jeg vist, at UNHCR og andre nødhjælpsorganisationer opretholdt idéen om flygtninge som ofre ved at skelne stærkt mellem god og dårlig folkelig deltagelse i lejren, hvor den gode deltagelse antages for at være upartisk, magtfrit og til det fælles bedste, er politisk, magtgrisk og selvisk deltagelse uønsket. Ved at erklære, at det blot er nogle individer, der saboterer fællesskabet, kan man opretholde idéen om et fællesskab af uskyldige ofre. I forbindelse med at uddrive disse individers uheldige indflydelse er man nødt til at kategorisere dem. Og her er det, at gængse opfattelser af køn og krig spiller ind, idet alle unge mænd gøres til genstand for mistænksomhed, mens kvinder (samt børn og ældre mænd) anses for at være de 'rene', xgte ofre som kan udgøre kernen i et flygtningefællesskab. Dette har to konsekvenser. For det første forklarer det, hvorfor UNHCR på den ene side kan tale om folkelig deltagelse og 'empowerment' af flygtninge, mens organisationen på den anden side holder flygtningene i en kort snor. Når den unge 'field assistant', som vi så i indled- ningen, holder møde med de valgte flygtningerepræsentanter, er det udtryk for en vilje til at skabe mere folkelig deltagelse i lejren. Når hun så kræver, at man laver udvalg bestående af tre mænd og tre kvinder, er det fordi hun (i lighed med sine overordnede) ikke mener, den nuværende folkelig deltagelse - med 95\% mandlige ledere - er tilfredsstillende. Og hendes paternalistiske attitude viser, at hun mener at vide, hvad der tjener flygtningene bedst - uanset hvad de selv måtte mene. For det andet har det konsekvenser for den måde, hvormed henholdsvis mænd og kvinder kan manøvrere og positionere sig i lejren. Andetsteds har jeg vist, at unge mænd må forholde sig til denne positionering som potentielle ballademagere (Turner 1999, 2000, 2001). Dette gør de dels ved at forsøge at spille rollen som offer og derved undgå at blive slået i hartkorn med politikere og voldsmænd. De lærer nødhjælpsjargonen og lærer at tale om PTSS (post traumatic stress syndrome), sårbare grupper, folkelig deltagelse og 'the community'. Pà den måde formår de at begå sig med de internationale organisationer. De bliver, hvad jeg kalder, 'liminale eksperter', idet de formår at udnytte det nye rum, flygtningene befinder sig i. Disse unge mænd klarer sig bedre end både de ældre mænd og kvinderne i lejren og får en central position. Dermed opstår en paradoksal situation, hvor den gruppe, der får mindst opmærksomhed i UNHCRs programmer og som mistænkeliggøres af de internationale organisationer, faktisk får en central position. Og denne position opnår de i høj grad gennem deres forbindelser til de selv samme organisationer.

Siden flygtningestudier tog fart for omtrent tyve år siden, har køn altid været et centralt tema i forskningen. Dog er der stadig en tendens til, at studier af kønsforhold i flygtningelejre forbliver studier af kvinder. ${ }^{5}$ Mrnds køn tages enten for givet (White 1997, 14) eller antages blot at være det modsatte af kvinders (Gilmore 1990). 
Med Judith Larges ord: 'That women's positions, interests and choices are influenced by their gender is recognised; the fact that men's situations are similarly affected by gender is not'(Large 1997, 25). De eneste undtagelser inden for flygtningestudier, mig bekendt, er Mark Sommers' analyser af unge Burundiske mænd i Dar-es-Salaam, hvor han dog ikke beskæftiger sig meget med køn som analytisk redskab (Sommers 2001), og Cathrine Bruns analyser af internt fordrevne i Sri Lanka (Brun 2000). Denne tendens til at ignorere mænd $\mathrm{i}$ analysen af køn i flygtningesituationer kan muligvis hænge sammen med opfattelsen af offeret, som er en bærende drivkraft både i meget kønsforskning og i særdeleshed i meget flygtningeforskning. 6 I form af, hvem det er 'mest synd for', er der ingen tvivl om, at kvinderne i lejren har det sværere end de unge mænd. Der er en stor gruppe unge mænd, der klarer sig særdeles godt i lejren, som beskrevet ovenfor. Derfor må vi huske på, at et skift til mænds køn ikke er et spørgsmål om at skabe medlidenhed med mændene og vise, at mænd også har problemer (White 1997, 21). Derimod har jeg i det ovenstående forsøgt at undgå denne 'victimologi' og i stedet undersøge, hvorledes opfattelser af offeret, flygtninge og køn er med til at strukturere lejren og dermed med til at kønne dens indbyggere.

\section{Noter}

1. Jeg vil ikke give en uddybende analyse af betydningen af nødhjælpsarbejdernes køn, alder, nationalitet og hudfarve. Flygtningene har en lang, kompleks hierarkisering af de forskellige organisationer og af de forskellige medarbejdere, baseret på nationalitet, køn, hudfarve og personlighed. Jeg nævner det her, dels fordi det er påfaldende, at en ung kvinde har så meget magt over de mandlige ledere, dels for at forhindre det stereotype billede i at opstå, som mange har af den internationale FNarbejder som en hvid mand.

2. Senest af US Committee for Refugees (US Committee for Refugees 2000).
3. For en uddybning henvises til min afhandling (Turner 2001).

4. Robert Chambers menes at have sat gang i debatten om participation internationalt (Chambers 1983), mens John Martinussen menes at have lanceret det danske begreb 'folkelig deltagelse' (Martinussen 1987).

5. Se blandt andet (Benjamin 1998; Daley 1991; Hyndman 2000; Indra 1999).

6. Marion Fresia leverer en meget bidende kritik af den angelsaksiske antropologiske studier af flygtninge, der ifølge hende svinger mellem 'heorisme' og 'miserabilisme' (Fresia 2002).

\section{LITTERATUR}

- Benjamin, Judy (1998): "Issues of power and empowerment in refugee studies: Rwandan women's adaptive behaviour in Benaco refugee camp" in Refuge, Canada's periodical on refugees 17(4).

- Brun, Cathrine (2000): "Making Young Displaced Men Visible" in Forced Migration Review 9. - Chambers, Robert (1983): Rural Development: putting the last first, Longman, London.

- Cruikshank, Barbara (1999): The Will to Empower: democratic citizens and other subjects, Cornell University Press, Ithaca.

- Daley, Patricia (1991): “Gender, displacement and social reproduction: settling Burundi refugees in Western Tanzania" in Journal of Refugee Studies $4(3)$.

- Duffield, M. (1996): "The Symphony of the Damned: Racial discourse, complex political emergencies and humanitarian aid" in Disasters 20(3).

"Executive Committee of The High Commissioner's Programme". UNHCR Policy on Refugee Women: UNHCR.

- Frazer, Elizabeth (1999): The Problems of Communitarian Politics: unity and conflict, Oxford University Press, New York.

- Fresia, Marion (2002): “Aide humanitaire et production de services publics et collectifs en Afrique de l'Ouest". Præsentation ved konferencen: $L a$ gouvernance au quotidien en Afrique: les relations entre services publics et collectifs et leurs usagers, Leiden.

- Gilmore, David D. (1990): Manhood in the Making: cultural concepts of masculinity, Yale University Press, New Haven.

. Hall-Matthews, David (1996): "Historical Roots of Famine Relief Paradigms: Ideas on Dependency and Free Trade in India in the 1870s" in Disasters 20(3).

- Harrell-Bond, Barbara E. (1986): Imposing Aid: 
emergency assistance to refugees, Oxford University

Press, New York.

- Human Rights Watch (2000): Seeking Protection: Addressing Sexual and Domestic Violence in Tanzania's Refugee Camps.

- Hyndman, Jennifer (2000): Managing Displacement: refugees and the politics of humanitarianism, University of Minnesota Press, Minneapolis.

- Indra, Doreen Marie (1999): Engendering Forced Migration: theory and practice, Berghahn Books,

New York.

- International Crisis Group (1999): Burundian

Refugees in Tanzania: The Key Factor to the Burundi Peace Process, ICG Central Africa Report No. 12.

- Kaur, Ravinder (2003): Unfinished Ph.D.

. Kibreab, Gaim (1993): "The Myth of Dependency among Camp Refugees in Somalia 1979-1989" in Journal of Refugee Studies 6(4).

- Large, Judith (1997): "Disintegration conflicts and the restructuring of masculinity", in Men and Masculinity, ed. C. Sweetman. Oxfam, Oxford. - Malkki, Liisa H. (1995): Purity and Exile: violence, memory, and national cosmology among Hutu refugees in Tanzania, University of Chicago Press, Chicago.

- Martinussen, John (1987): Politik og udvikling $i$ den 3. verden - en introduktion til økonomisk og politisk udviklingsteori, Mellemfolkeligt Samvirke, København.

- Moser, Caroline O. N., and Fiona C. Clark (2001): Victims, Perpetrators or Actors?: gender, armed conflict and political violence, Zed Books, London and New York.

. Rajaram, Prem Kumar (2002): "Humanitarianism and Representations of the Refugee" in Journal of Refugee Studies 15(3).

- Reynolds, Richard (1995): "Development in a refugee situation: The case of Rwandan refugees in Tanzania”, Refugee Participation Network (18). - Reynolds, Richard (1996): “Community Services and repatriation", Refugee Participation Network (22).

- Soguk, Nevzat (1999): States and Strangers: refugees and displacements of statecraft, University of Minnesota Press, Minneapolis.

- Sommers, Marc (2001): Fear in Bongoland: Burundi refugees in urban Tanzania, Berghahn Books, New York.

- Taylor, Charles (1994): “The Politics of Recognition" in Multiculturalism: examing the politics of recognition, eds. C. Taylor and A. Gutmann.

Princeton University Press, Princeton.

- Turner, Simon (1999): “Angry Young Men in Camps: gender, age and class relations among $\mathrm{Bu}-$ rundian refugees in Tanzania" in New Issues in Refugee Research (UNHCR Working Paper No. 9). . Turner, Simon (2000): "Vindicating Masculinity: the fate of promoting gender equality" in Forced Migration Review (9):8-10.

- Turner, Simon (2001): The Barriers of Innocence - humanitarian intervention and political imagination in a refugee camp for Burundians in Tanzania, ph.d.afhandling Roskilde Universitetscenter.

- UNHCR (1991): Guidelines on the Protection of Refugee Women, Geneva: Office of the United Nations High Commissioner for Refugees.

. US Committee for Refugees (2000): "More Male Refugees than Previously Thought" in Refugee Reports $2 \mathrm{l}(2)$.

- Varley, A. (1995): "Neither Victims nor Heroines - Women, Land and Housing in Mexican Cities" in Third World Planning Review 17(2).

- Varley, A. (1996): "Women heading households: Some more equal than others?" in World Development 24(3).

- White, Sarah (1997): “Men, Masculinities and the Politics of Development in Men and Masculinity, ed. C. Sweetman. Oxfam, Oxford.

\section{SUMMARY}

This article explores the ways in which international humanitarianism produces refugees as victims through discourse and specific governmental practices in a refugee camp. It shows how such constructions of victimbood are gendered, with women (and children) representing the refugee as the innocent victim while men are perceived in more ambiguous terms. Through ethnographic evidence from a refugee camp in Tanzania, the article shows that refugees do not, however, act as passive and bence innocent - victims of circumstance, but actively take part in shaping their lives through political and at times violent mobilisation. This poses a dilemma for humanitarian agencies, a dilemma that they attempt to solve by distinguishing between a community of innocent victims and a bandful of male politicians who are allegedly sabotaging this community spirit.

Simon Turner, ph.d., adjunkt Internationale Udviklingsstudier, RUC 